\title{
KONSEP PEMBELAJARAN MATEMATIKA DALAM MENCAPAI HASIL BELAJAR MENURUT TEORI GAGNE
}

\author{
Oleh: Mariam Nasution ${ }^{1}$
}

\begin{abstract}
In achieving learning outcomes in mathematics learning that is brought about by Gagne is the task of a teacher to understand in advance what to do and prepare students in order to achieve learning goals or learning outcomes. The concept of mathematical learning according to Gagne Theory there are several kinds of learning outcomes namely verbal information, intellectual skills, cognitive strategies, attitudes and motor skills. The learning outcomes that will be achieved according to Gagne are as follows: (1) Verbal Information. Verbal information capability is the ability to communicate verbally his knowledge of facts. Verbal information is obtained verbally, reading books and so on. This information can be classified as facts, principles, generalization names, (2) Intellectual Skills are the capabilities of intellectual skills to be able to distinguish, master concepts, rules, and solve problems. These abilities are obtained through learning. (3) Cognitive Strategy. Cognitive strategy capability is the ability to coordinate and develop thought processes by recording, making analysis and synthesis,

(4) Attitudes. The tendency to respond appropriately to the stimulus on the basis of the assessment based on the stimulus. The response given by someone to an object might be a positive maybe negative. Depending on the assessment of the object in question, (5) Motor skills are a person's skills can be seen from the speed, accuracy, and smooth movement of the muscles and bodies shown by the person in learning.
\end{abstract}

\section{Abstrak}

Dalam mencapai hasil belajar dalam pembelajaran matematika yang dikemukan oleh Gagne merupakan tugas seorang guru untuk memahami lebih dahulu tentang apa yang hendak dilakukan dan mempersiapkan peserta didik dalam rangka pencapaian tujuan belajar atau hasil belajar. Konsep pembelajaran matematika menurut Teori Gagne terdapat beberapa macam hasil belajar yaitu informasi verbal, Keterampilan intlektual, Strategi kognitif, 
sikap dan keterampilan motorik. Adapun hasil belajar yang akan di capai menurut Gagne sebagai berikut: (1) Informasi Verbal. Kapabilitas informasi verbal merupakan kemampuan untuk mengkomunikasikan secara lisan pengetahuannya tentang fakta-fakta. Informasi verbal diperoleh secara lisan, membaca buku dan sebagainya. Informasi ini dapat diklasifikasikan sebagai fakta, prinsip, nama generalisasi;

(2) Keterampilan Intelektual merupakan kapabilitas keterampilan intelektual untuk dapat memperbedakan, menguasai konsep, aturan, dan memecahkan masalah. Kemampuan-kemampuan tersebut diperoleh melalui belajar; (3) Strategi Kognitif. Kapabilitas strategi kognitif adalah kemampuan untuk mengkoordinasikan serta mengembangkan proses berpikir dengan cara merekam, membuat analisis dan sintesis; (4) Sikap. Kecenderungan merespon secara tepat terhadap stimulus atas dasar penilaian berdasarkan stimulus tersebut. Respon yang diberikan seseorang terhadap suatu objek mungkin positif mungkin pula negatif. Tergantung penilaian terhadap objek yang dimaksud; (5) Ketrampilan motorik merupakan keterampilan seseorang bisa dilihat dari kecepatan, ketepatan, dan kelancaran gerakan otot-otot serta badan yang diperlihatkan oleh orang tersebut dalam belajar.

\section{PENDAHULUAN}

Dalam mencapai kualitas pendidikan dalam sekolah tidak terlepas dari proses belajar mengajar yang baik. Proses belajar mengajar ini merupakan salah satu indikator yang penting dilaksanakan dikelas yang terdiri dari komponen guru, siswa, sumber belajar, sarana dan prasarana, dan tidak kalah pentingnya yaitu kompetensi seorang guru dalam menguasai bidang Paedagogik. Dalam hal ini penguasaan seorang guru dan cara menyampaikannya merupakan syarat yang sangat essensial. Penguasaan guru terhadap materi pelajaran dan pengelolaan kelas sangatlah penting, namun demikian belum cukup untuk menghasilkan pembelajaran yang optimal. Selain menguasai materi matematika guru sebaiknya menguasai tentang teori-teori belajar, agar dapat mengarahkan peserta didik berpartisipasi secara intelektual dalam belajar, sehingga belajar menjadi bermakna bagi siswa. Hal ini sesuai dengan isi lampiran Peraturan Menteri Pendidikan Nasional (Permendiknas) Nomor 16 Tahun 2007 tentang Standar Kualifikasi Akademik dan Kompetensi Guru yang menyebutkan bahwa penguasaan teori belajar dan prinsip-prinsip pembelajaran yang mendidik menjadi salah satu unsur kompetensi pedagogik yang harus dimiliki guru. Jika seorang guru akan menerapkan suatu teori belajar dalam proses belajar mengajar, maka guru tersebut 
harus memahami seluk beluk teori belajar tersebut sehingga selanjutnya dapat merancang dengan baik bentuk proses belajar mengajar yang akan dilaksanakan.

\section{PEMBAHASAN}

Dalam pembelajaran matematika seorang guru hendaknya berupaya membuat proses pembelajaran secara bermakna. Membelajarkan siswa merupakan tugas utama seorang guru matematika agar siswanya dapat

melakukan kegiatan-kegiatan dalam mencapai tujuan pembelajaran. Pembelajaran di pandang berhasil apabila di dalam diri siswa telah terjadi perubahan baik dari segi pisik dan pengalaman. Sesuai pendapat Gagne dan Berliner (dalam Catharina Tri anni) menyatakan bahwa terjadi peritiwa belajar dimana suatu organisme mengubah perilakunya karena hasil pengalaman. ${ }^{1}$ Begitu juga menurut Gagne sendiri (dalam dahar) Belajar adalah suatu proses di mana suatu organisasi (siswa) berubah perilakunya akibat dari suatu pengalaman. ${ }^{2}$

Konsep pembelajaran matematika menurut Teori Gagne terdapat beberapa macam hasil belajar (dalam Drisscoll) yaitu informasi verbal, Keterampilan intlektual, Strategi kognitf, sikap dan keterampilan motorik. ${ }^{3}$ Dalam mencapai hasil belajar dalam pembelajaran matematika yang dikemukan oleh Gagne tentu seorang guru akan memahami lebih dahulu tentang apa yang hendak dilakukan dan mempersiapkan peserta didik dalam rangka pencapaian tujuan belajar atau hasil belajar. Adapun hasil belajar yang akan di capai menurut Gagne sebagai berikut:

\section{Informasi Verbal}

Menurut Ruseffendi (dalam Upu) rangkaian verbal merupakan perbuatan lisan terurut dari dua rangkaian kegiatan atau lebih kegiatan stimulus respon. ${ }^{4}$ Dalam hal ini guru dapat memberikan berupa pertanyaan kepada siswa untuk melatih siswa dalam menjawab secara lisan, menulis dan menggambar. Sesuai pendapat Gagne (dalam Slameto bahwa belajar verbal

\footnotetext{
${ }^{1}$ Chatarina Tri Anni, 2005. Psikologi Belajar. (Semarang: UPT MKK UNNES). hlm 2

2 Dahar, R.w, 2011. Teori-Teori Pembelajaran, (Jakarta: Erlangga) Education)

3 Drisscoll, M.P, 2005, Psichologi of Learning For Intruction, (New Jersey: Pearson

4 Hamzah, Upu, 2008. Teori Belajar Pendukung Pendekatan Pengajuan Masalah Matematika
} 
adalah belajar mengenai materi verbal melalui latihan dan ingatan. ${ }^{5}$ Dalam setiap pembelajaran diperlukan kemampuan verbal, begitu pula untuk pembelajaran matematika yang mana kemampuan verbal ini perlu di kuasai siswa di samping kemampuan berhitung. Dalam pembelajaran matematika selalu berhubungan dengan lambang-lambang, angka dan simbol-simbol lainnya dan matematika tidak terlepas dari kemampuan pemecahan masalah. Oleh sebab itu kemampuan verbal ini salah satu yang harus dikuasai oleh siswa dalam menentukan hasil belajar. kemampuan verbal yang dapat dilakukan siswa dalam kegiatan belajar yaitu: menyebutkan konsep, defenisi, aturanaturan dan prinsip dan dapat dilanjutkan dengan menulis serta menggambar. Guru matematika dapat memberi pertanyaan kepada siswa yang memberi jawaban sebagai informasi verbal misalnya: (1) sebutkan yang anda ketahui tentang unsur-unsur lingkaran dan gambarkan dalam catatanmu (2) Jika luas lingkaran adalah $16 / \mathrm{cm}^{2}$, hitunglah kelilingnya.(3) Jarak antara dua pusat dua buah lingkaran adalah $13 \mathrm{~cm}$. Jika jari-jari kedua lingkaran itu adalah $7 \mathrm{~cm}$ dan 2 $\mathrm{cm}$, maka hitunglah panjang garis singgung persekutuan luar. Jadi dapat disimpulkan kemampuan verbal adalah suatu kemampuan yang harus di kuasai siswa dalam belajar matematika dan dapat mengekpresikannya bentuk lisan,tulisan dan gambar.

\section{Keterampialan Intelektual}

Keterampilan intelektual dalam pembelajaran matematika adalah kemampuan menggunakan kecerdasan untuk memecahkan masalah. Dalam proses pembelajaran, pengetahuan bersumber dari materi subjek.

Keterampilan-keterampilan intelektual memungkinkan seseorang berinteraksi dengan lingkungannya melalui penggunaan simbol-simbol atau gagasangagasan. Belajar keterampilan intelektual telah dimulai sejak

tingkat-tingkat pertama sekolah dasar dan dilanjutkan sesuai dengan perhatian dan kemampuan intelektual seseorang. Keterampilan intelektual ini sering disebut Ranah kognitif. Ranah kognitif adalah ranah yang mencakup kegiatan mental (otak). Segala upaya yang menyangkut aktivitas otak adalah termasuk dalam ranah kognitif. Ranah kognitif memiliki enam jenjang atau aspek, yaitu:

1. Pengetahuan/hafalan/ingatan (knowledge)

2. Pemahaman (comprehension)

${ }^{5}$ Slameto, 2003. Belajar dan Faktor-Faktor yang Mempengaruhinya, (Jakarta: Rineka Cipta) 
3. Penerapan (application)

4. Analisis (analysis)

5. Sintesis (syntesis)

6. Penilaian/penghargaan/evaluasi (evaluation)

Tujuan aspek kognitif berorientasi pada kemampuan berfikir yang mencakup kemampuan intelektual yang lebih sederhana, yaitu mengingat, sampai pada kemampuan memecahkan masalah yang menuntut siswa untuk menghubungkan dan menggabungkan beberapa ide, gagasan, metode atau prosedur yang dipelajari untuk memecahkan masalah tersebut. Dengan demikian aspek kognitif adalah subtaksonomi yang mengungkapkan tentang kegiatan mental yang sering berawal dari tingkat pengetahuan sampai ke tingkat yang paling tinggi yaitu evaluasi.

Dalam pembelajaran kemampuan utama yang diukur sebagai hasil pencapaian belajar adalah kemampuan kognitif siswa. Menurut Gagne, keterampilan kognitif merupakan kemampuan yang membuat individu menjadi berkompeten. ${ }^{6}$ Tujuan mata pelajaran menguraikan beberapa kompeten yang harus dicapai siswa. Dari situlah guru melaksanakan pembelajaran secara formal dengan menyampaikan ilmu kepada siswa agar mencapai kompetensi. Sebagai contoh dalam pembelajaran matematika, kompetensi yang harus dicapai seperti 'menentukan luas selimut dan volume tabung, kerucut, dan bola menaksir dan mengitung luas permukaan bangun datar dan bangun ruang yang tidak beraturan dengan menerapkan kombinasi geometri dasarnya atau menentukan peluang suatu kejadian sederhana secara empirik dan teoritik.

Keterampilan intelektual dibedakan lagi berdasarkan jenisnya, seperti diskriminasi-diskriminasi, konsep-konsep konkret, konsep-konsep definisi, aturan-aturan, yaitu kemampuan merespons hubungan-hubungan antara objekobjek dan kejadian-kejadian, aturan tingkat tinggi, yaitu kemampuan merespons hubungan-hubungan antara objek-objek dan kejadian-kejadian secara lebih kompleks dan yang terakhir memecahkan masalah.

3. Strategi Kognitif

Strategi kognitif merupakan hal yang sangat penting dalam keterampilan. Kemampuan ini mampu mengatur individu itu sendiri, mulai dari mengingat, berpikir, dan berperilaku. Hal ini menjadi tujuan utama dalam pendidikan untuk mengembangkan kreativitas siswa dalam pemecahan masalah. Ada lima jenis strategi-strategi kognitif, antara lain; strategi-strategi menghafal, strategi-strategi

\footnotetext{
${ }^{6}$ Gagne, Robert,1983, The Conditioning of Learning, (Japan: Holt saunders)
} 
elaborasi, strategi-strategi pengaturan, strategi-strategi pemantauan pemahaman, dan strategi-strategi afektif. Menurut Bell Gredler, menyebut strategi kognitif sebagai suatu proses berfikir induktif, yaitu membuat generalisasi dari fakta, konsep, dan prinsip sesuai yang diketahui seseorang. ${ }^{7}$ Selanjutnya McDevitt dan Ormrod, mendefinisikan strategi kognitif sebagai "specific mental process that people use to acquire or manipulation information." Jadi, yang dimaksud dengan strategi kognitif adalah proses mental atau kognitif tertentu yang digunakan orang untuk memperoleh atau memanipulasi informasi. ${ }^{8}$ Pendapat serupa dikemukakan Gagne (dalam Paulina dan Malati) strategi kognitif adalah kemampuan internal yang terorganisasi yang dapat membantu siswa dalam proses belajar, proses berpikir, memecahkan masalah, dan mengambil keputusan. ${ }^{9}$ Dalam pendapat yang lain dikatakan "Cognitive Strategy Instruction (CSI) is a very broad subject but here you will find anoverview of the process and practical tips. For more in depth study references are provided. CSI is a tool intended to help students develop the necessary skills to be selfregulated learners". 10

Jika strategi kognitif disematkan pada pembelajaran matematika, maka terdapat kompetensi-kompetensi yang harus ditanamkan pada siswa. Pembelajaran matematika ditujukan agar siswa tidak hanya menghafal rumusrumus matematika saja, tetapi juga dapat mengaitkan pokok bahasan sebelumnya yang relevan, mengelompokkan konsep-konsep menjadi kategori yang bermakna; misal materi geometri dimensi satu yaitu titik, dimensi dua yaitu titik dan garis yang membentuk bangun datar, dan dimensi tiga yaitu titik, garis, bidang, bangun ruang., kemudian belajar dengan mengetahui proses yang sedang dilakukan yang terakhir belajar dan memusatkan perhatian. Dalam upaya untuk mengembangkan strategi kognitif anak, maka guru melakukan perencanaan pembelajaran dengan memperhatikan hal-hal berikut; kinerja, kondisi internal dan kondisi eksternal.

Strategi kognitif merupakan kemampuan yang datangnya dari dalam individu itu sendiri. Oleh karena itu guru harus mengetahui karakteristik yang dimiliki siswa. Kapasitas intelektual dari siswa berbeda-beda, karena faktor keturunan/genetik memiliki pengaruh. Guru tidak bisa memaksakan semua siswa

7 Bell-Geller, M.E. 1986. Learning and Instruction: Theory into Practice, (New York: Macmillan Publishing Company).

${ }^{8}$ McDevitt, T. M., dan Ormrod, J. E. 2002.Child development: Educating and working with children and adolescents, 2nd ed. (Upper Saddle River: Pearson Merrill Prentice Hall)

9 Paulina, P. dan Malati, I. 1997.Strategi Kognitif, (Jakarata: Direktorat Jendral Pendidikan Tinggi Departemen Pendidikan Nasional)

${ }^{10}$ Reid, B. Cognitive Strategy Instruction, Lincoln: Dept. of Special Ed \&Communication Disorders, 2006 
memiliki pemikiran yang seragam antara satu dan lainnya. Strategi kognitif berpotensi digunakan dalam semua cabang ilmu Matematika. Tergantung dari bagaimana seorang guru mengarahkan siswanya untuk menemukan rumus-rumus atau teoremateorema yang berkaitan dengan cabang ilmu matematika yang diajarkan. Misalnya pelajaran bidang datar, awalnya siswa hanya diberitahu tentang luas segi empat. Selanjutnya siswa diminta menemukan sendiri bagaimana mendapatkan rumus luas segitiga, layang-layang, belah ketupat, trapesium, lingkaran, dan sebagainya. Jika guru menerapkan metode seperti itu, maka siswa akan berpikir secara mandiri dan menggunakan strategi kognitifnya masing-masing.

\section{Sikap}

Salah satu tujuan pendidikan matematika adalah pembentukan sikap siswa. Oleh karena itu, sudah sepatutnya dalam proses pembelajaran matematika perlu diperhatikan sikap siswa terhadap matematika. Hal ini penting mengingat sikap positif terhadap matematika akan berkorelasi positif dengan prestasi belajar matematika. Sikap adalah merupakan suatu komponen yang sangat mempengaruhi keberhasilan program pembelajaran matematika. Seseorang yang memiliki sikap positif akan menunjukkan tindakan yang selalu mengarah pada upaya pencapaian tujuan pembelajaran matematika.

Salah satu hal yang perlu diperhatikan seorang pengajar dalam mensukseskan pembelajarannya adalah menciptakan suatu kondisi dan iklim pembelajaran yang bisa merangsang dan meningkatkan sikap positif siswa dalam pembelajaran matematika. Menurut Berkowitz (dalam Azwar) sikap seseorang terhadap suatu objek adalah perasaan mendukung (favorable) atau tidak mendukung (unfavorable) terhadap objek tersebut. ${ }^{11}$ Selanjutnya Peraturan Menteri Pendidikan Nasional No 22 (Depdiknas, 2006) tentang Standar Isi Mata Pelajaran Matematika menyatakan bahwa tujuan nomor 5 pelajaran matematika di sekolah adalah agar para siswa: "Memiliki sikap menghargai kegunaan matematika dalam kehidupan, yaitu memiliki rasa ingin tahu, perhatian, dan minat dalam mempelajari matematika, serta sikap ulet dan percaya diri dalam pemecahan masalah."12 Maka guru perlu mengarahkan siswa agar dapat menunjukkan sikap yang positif terhadap pembelajaran matematika. Dalam pembelajaran matematika, terdapat banyak sikap yang dapat dikembangkan seperti berpikir kreatif, rasa ingin tahu

${ }^{11}$ Azwar, Saifuddin. (1995). Sikap Manusia, Teori dan Pengukurannya. (Yogyakarta: Liberty). hlm.5

12 Depdiknas (2006). Permendiknas Nomor 22 Tahun 2006 Tentang Standar Isi Sekolah Menengah Atas. (Jakarta: Depdiknas). 
yang tinggi, bertanggung-jawab dan sabar. Dalam merancang pembelajaran yang mengembangkan kemampuan sikap siswa, guru apa mengamati respons siswa misalnya ketika dihadapkan pada persoalan matematika, ataupun saat diskusi kelas. Guru bisa mengamati bagaimana sikap siswa, apakah antusias dalam mengerjakan matematika maupun dalam diskusi kelas atau tidak.

Ranah afektif adalah ranah yang berkaitan dengan sikap dan nilai. Ranah afektif mencakup watak perilaku seperti perasaan, minat, sikap, emosi, dan nilai. Beberapa pakar mengatakan bahwa sikap seseorang dapat diramalkan perubahannya bila seseorang telah memiliki kekuasaan kognitif tingkat tinggi. Ciri-ciri hasil belajar afektif akan tampak pada peserta didik dalam berbagai tingkah laku.

Ranah afektif menjadi lebih rinci lagi ke dalam lima jenjang, yaitu:

1. Receiving atau attending (menerima atau memperhatikan)

2. Responding (menanggapi) mengandung arti "adanya partisipasi aktif"

3. Valuing (menilai atau menghargai)

4. Organization (mengatur atau mengorganisasikan)

5. Characterization by evalue or calue complex (karakterisasi dengan suatu nilai atau komplek nilai).

Jadi dapat di simpulkan sikap merupakan suatu perhatian, penghargaan, respon, organisasi dalam menerima pembelajaran matematika sehingga siswa dapat mengembangkan kreativitasnya.

\section{Keterampilan Motorik}

Keterampilan Motorik merupakan sebuah proses dimana seseorang mengembangkan seperangkat respons kedalam suatu gerak yang terkoordinasi, terorganisasi, dan terpadu. ${ }^{13}$ Sebuah keterampilan motorik adalah salah satu jenis kemampuan manusia yang paling jelas untuk diamati. Kemahiran ini merupakan kemampuan siswa untuk melakukan sesuatu dengan menggunakan mekanisme otot yang dimiliki. Untuk mengetahui seseorang memiliki kapabilitas keterampilan motorik, kita dapat melihatnya dari segi kecepatan, ketepatan, dan kelancaran gerakan otot-otot, serta anggota badan yang diperlihatkan orang tersebut.

Beberapa hal penting dalam mempelajari keterampilan motorik menurut Hurlock meliputi: ${ }^{14}$

13 Lutan, Rusli, 1988. Belajar Keterampilan Motorik Pengantar Teori dan Metode. (Jakarta: P2LPTK Dirjen Dikti Depdikbud)

14 Hurlock, Elizabeth B. 2001. Perkembangan Anak Jilid 1.(Jakarta: Erlangga) 
a. Kesiapan belajar.

Seorang siswa akan dapat berhasil atau tidak dalam mempelajari matematika tergantung bagaimana kesiapan anak dalam menerima pembelajaran itu sendiri. Kesiapan belajar merupakan hal yang penting diperhatikan oleh guru ketika hendak melakukan proses pembelajaran. Kesiapan belajar itu adalah kondisi awal suatu kegiatan belajar yang membuatnya siap untuk memberi respon/jawaban yang ada pada diri siswa dalam mencapai tujuan pengajaran tertentu. ${ }^{15}$. Seorang pembelajar harus menyadari bahwa dalam belajar itu harus dalam keadaan siap kognitif, afektif dan psikomotorik. Bila siswa tidak memiliki kesiapan maka niscaya tujuan pembelajaran tidak akan tercapai. b. Kesempatan belajar.

Guru sebagai penggerak utama di sekolah terutama dalam hal mentransfer ilmu pengetahuan, membimbing dan mengarahkan siswa, harus senantiasa dapat memberikan kesempatan belajar bagi seluruh siswa tanpa pandang buluh. Guru dapat memberi kesempatan kepada peserta didik untuk menguasai materi pembelajaran sesuai usia dan kemampuan belajarnya melalui pengaturan proses pembelajaran dan aktivitas yang bervariasi. Pemberian kesempatan kepada siswa untuk mengeloxplrasi pengetahuannya sangat mementukan keberhasilan seseorang.

c. Kesempatan berpraktek

Dalam proses belajar mengajar matematika, siswa bukan saja mempelajari pengetahuan secara teori tetapi kesempatan mempelajari praktikpun harus dilakukan. Praktek yang dimaksud dalam pembelajaran matematika adalah mengunakan media ataupun alat peraga

Dalam pembelajaran matematika, media pembelajaran merupakan aspek penting yang dapat menunjang keberhasilan belajar. Media pembelajaran ini fungsinya adalah sarana untuk memudahkan anak dalam memahami materi yang disampaikan guru. Siswa akan lebih mudah paham karena media pembelajaran biasanya adalah sesuatu hal yg konkret. Media pembelajaran matematika sering kita sebut dengan alat peraga matematika. Apa sajakah contoh alat peraga matematika sebagai alat peraga edukatif dalam pembelajaran? Misalnya mempergunakan neraca bilangan, papan berbaku (geoboard), alat peraga jam sudut, menara hanoi, kerangka bangun ruang dan sebagainya

15 Slameto. 2010.Belajar dan Faktor-Faktor yang Mempengaruhinya. (Jakarta: Rineka 
Menurut Estiningsih alat peraga merupakan media pembelajaran yang mengandung atau membawakan ciri-ciri konsep yang dipelajari. ${ }^{16}$ Contoh papan tulis, buku tulis, dan daun pintu yang berbentuk persegi panjang dapat berfungsi sebagai alat peraga pada saat guru menerangkan bangun geometri yang berbentuk persegi panjang. Fungsi utama alat peraga adalah untuk menurunkan keabstrakan dari konsep, agar anak mampu menangkap arti sebenarnya dari konsep yang dipelajari. Dengan melihat, meraba, dan memanipulasi alat peraga maka anak mempunyai pengalaman nyata dalam kehidupan tentang arti konsep. Sedangkan sarana merupakan media pembelajaran yang fungsi utamanya sebagai alat bantu untuk melakukan pembelajaran. Dengan menggunakan sarana tersebut diharapkan dapat memperlancar pembelajaran. Contoh: papan tulis, jangka, penggaris, LT (lember tugas), LK (lembar kerja), alat-alat permainan.

d. Model yang baik

Model dan pendekatan pada pembelajaran matematika sangat memiliki peranan yang sangat penting dalam pembelajaran. Karena model-model dan pendekatan pada matematika akan membawa setiap siswa untuk kita sebagai pelajaran untuk menjdi lebih efektif dalam belajar. Tentunya seorang guru, dituntut untuk mampu mengembangkan serta menerapkankannya dalam proses pembelajaran. Sehingga dengan demikian efektivitas pembelajaran matematika akan berjalan dengan baik dan berkualitas. Arends dalam Trianto model pembelajaran mengacu pada pendekatan pembelajaran yang akan digunakan, termasuk di dalamnya tujuan-tujuan pengajaran, tahap-tahap dalm kegiatan pembelajaran, lingkungan pembelajaran, dan pengelolaan kelas. ${ }^{17}$ Model pembelajaran apapun yang digunakan oleh guru hendaknya dapat mengakomodasi menyeluruh terhadap prinsip-prinsip pembelajaran yang berpusat pada anak didik (student oriented)

e. Bimbingan

Bimbingan belajar merupakan bagian terpenting bagi peserta didik, mengingat pada saat ini peserta didik dituntut untuk bisa berkompetensi. Oleh karena itu siswa diharapkan mengikuti bimbingan belajar sebagai alat untuk menghadapi tantangan di masa depan. Selain itu, manfaat dari bimbingan belajar adalah dapat membuat siswa semakin kreatif pada

\footnotetext{
Matematika)

${ }^{16}$ Estiningsih, E. 1994. Landasan Teknik Pengajaran Hitung SD. (Yogyakarta: PPPG

${ }^{17}$ Trianto. 2015. Model Pembelajaran Terpadu. (Jakarta: Bumi Aksara). hlm.51
} 
kegiatan belajar mengajar, dan dapat meningkatkan prestasi pada sekolahnya. Maka sangat penting bagi peserta didik untuk mengikuti bimbingan belajar, agar mereka mampu bersaing dengan tuntutan zaman pada saat ini. Manfaat Bimbingan Belajar bagi siswa adalah tersedianya kondisi belajar yang nyaman, terperhatikannya karakteristik pribadi siswa, dan siswa dapat mereduksi kemungkinan kesulitan belajar

f. Motivasi

Dalam belajar matematika, motivasi sangat diperlukan dalam menggiring siswa untuk dapat berbuat dan mendorong agar peserta didik lebih giat belajar tetapi kenyataannya, motivasi dalam belajar matematika kadang naik kadang turun, bahkan yang lebih banyak kita jumpai adalah selalu turun dikarenakan kemungkinan belajar matematika penuh dengan hitungan-hitungan, symbol-simbol dan bilangan-bilangan yang secara kasat mata tidak terlihat dan sepertinya sia-sia dalam belajar matematika, maka perlu semacam upaya yang dilakukan oleh guru guna meningkatkan motivasi dalam pembelajaran. Ali Imron dalam buku Teori Belajar dan Pembelajaran, Cet II (dalam Eveline Siregar dan Hartini Nara)

menguraikan empat upaya memotivasi belajar, adalah sebagai berikut: $^{18}$ a). Mengoptimalkan penerapan prinsip-prinsip belajar b). Megoptimalkan unsur-unsur dinamis pembelajaran

c.) Mengoptimalkan pemanfaatan upaya guru dalam membelajarkan siswa juga menjadi factor yang mempengaruhi motivasi. Jika guru tidak bergairah dalam proses pembelajaran maka akan cenderung menjadikan siswa tidak memiliki motivasi belajar, tetapi sebaliknya jika guru memiliki gairah dalam membelajarkan siswa maka siswa juga akan termotivasi. Hal-hal yang disajikan secara menarik oleh guru juga menjadi sesuatu yang mempengaruhi tumbuhnya motivasi siswa. d). Mengembangkan aspirasi dalam belajar.

g. Setiap keterampilan motorik harus dipelajari secara individu

Keterampilan motorik merupakan keterampilan menggunakan otot atau tubuh. Keterampilan ini bisa dilakukan siswa secara sendiri dalam pembelajaran matematika. Dalam pembelajaran matematika guru dapat memberikan berupa konsep, contoh dan latihan dan menggunakan alat 
peraga yang berhubungan dengan materi yang disampaikan agar siswa melakukan secara langsung dengan menggunakan motoriknya.

h. Keterampilan sebaiknya dipelajari satu persatu.

Tujuan akhir dari terampil belajar ialah dimilikinya kemampuan memecahkan masalah secara bertanggung jawab. Tanggung jawab ini memiliki makna yang sangat dalam, melampaui kemampuankemampuan lain yang diperoleh dari belajar. Untuk mencapai tujuan akhir tersebut, harus dilampaui dua tujuan antara, yakni: 19

(1) Mampu mengenali hakikat dirinya, potensi dan bakat-bakat terbaiknya, dan

(2) Dapat berusaha sekuat tenaga untuk mengaktualisasikan segenap potensinya, mengekspresikan dan menyatakan dirinya sepenuhnyaseutuhnya dengan cara menjadi diri sendiri. Dalam konteks yang lebih luas, yakni pendidikan, belajar keterampilan merupakan sub dari keterampilan belajar. Dalam keterampilan belajar, akan muncul keterampilan-keterampilan lain, baik yang bersifat kognitif, afektif, maupun psikomotor. Sedangkan dalam belajar keterampilan lebih condong dan dominan pada aspek psikomotor. Keterampilan belajar ini sebaiknya dipelajari secara bertahap dan berkesinambungan.

\section{PENUTUP}

Konsep pembelajaran matematika menurut Gagne menekankan pada stimulus respon. Belajar terjadi apabila suatu situasi stimulus bersama dengan isi ingatannya mempengaruhi siswa sedemikian rupa sehingga perbuatannya berubah dari sebelum ia mengalami situasi dengan setelah mengalami situasi tadi. Belajar dipengaruhi oleh faktor dalam diri dan faktor dari luar siswa di mana keduanya saling berinteraksi. Komponen-komponen dalam proses belajar menurut Gagne dapat digambarkan sebagai $S-R$. $S$ adalah situasi yang memberi stimulus, $R$ adalah respons atas stimulus itu, dan garis di antaranya adalah hubungan di antara stimulus dan respon yang terjadi dalam diri seseorang yang tidak dapat kita amati, yang bertalian dengan sistem alat saraf di mana terjadi transformasi perangsang yang diterima melalui alat dria. Stimulus ini merupakan input yang berada di luar individu dan respon adalah outputnya, yang juga berada di luar individu sebagai hasil belajar yang dapat diamati. 
Menurut Gagne belajar matematika terdiri dari objek langsung dan objek tak langsung. Objek tak langsung antara lain kemampuan menyelidiki, kemampuan memecahkan masalah, ketekunan, ketelitian, disiplin diri, bersikap positif terhadap matematika. Sedangkan objek tak langsung berupa fakta, keterampilan, konsep, dan prinsip

Gagne juga mengemukakan 5 macam hasil belajar atau kapabilitas tiga sifat kognitif, satu bersifat psikomotor, dan satu bersifat afektif sebagai berikut: (1) Informasi Verbal. Kapabilitas informasi verbal merupakan kemampuan untuk mengkomunikasikan secara lisan pengetahuannya tentang fakta-fakta. Informasi verbal diperoleh secara lisan, membaca buku dan sebagainya. Informasi ini dapat diklasifikasikan sebagai fakta, prinsip, generalisasi. Contoh, siswa dapat menyebutkan dalil Phytagoras yang berbunyi, "pada segitiga siku-siku berlaku kuadrat sisi miring sama dengan jumlah kuadrat sisi-sisi siku-sikunya. (2) Keterampilan Intelektual merupakan kapabilitas keterampilan intelektual untuk dapat memperbedakan, menguasai konsep, aturan, dan memecahkan masalah. Kemampuan-kemampuan tersebut diperoleh melalui belajar. (3) Strategi Kognitif. Kapabilitas strategi kognitif adalah kemampuan untuk mengkoordinasikan serta mengembangkan proses berpikir dengan cara merekam, membuat analisis dan sintesis. Kapabilitas ini terorganisasikan secara internal sehingga memungkinkan perhatian, belajar, mengingat, dan berfikir anak terarah. Contoh tingkah laku akibat kapabilitas strategi kognitif, adalah menyusun langkah-langkah penyelesaian masalah matematika. (4) Sikap. Kecenderungan merespon secara tepat terhadap stimulus atas dasar penilaian berdasarkan stimulus tersebut. Respon yang diberikan seseorang terhadap suatu objek mungkin positif mungkin pula negatif. Tergantung penilaian terhadap objek yang dimaksud. Contoh seseorang masuk kedalam toko buku disana dia melihat buku matematika, jika dia memiliki sikap positif terhadap matematika maka buku tersebut akan dibelinya, ataupun sebaliknya. (5) Ketrampilan motorik merupakan keterampilan seseorang bisa dilihat dari kecepatan, ketepatan, dan kelancaran gerakan otot-otot serta badan yang diperlihatkan oleh orang tersebut. Kemampuan dalam mendemonstrasikan alat peraga matematika seperti menggunakan penggaris ataupun jangka merupakan ketrampilan tingkah laku kapabilitas ini.

Jadi dapat disimpulkan konsep pembelajaran matematika menurut teori Gagne ini merupakan suatu prosedur pembelajaran yang perlu diketahui seorang guru matematika untuk mengembangkan keterampilan siswa dan kreativitas dalam rangka pencapaian hasil dan tujuan pembelajaran yang berkualitas. 


\section{DAFTAR PUSTAKA}

Azwar, Saifuddin, Sikap Manusia, Teori dan Pengukurannya, Yogyakarta: Liberty, 1995

Bell-Geller, M.E. Learning and Instruction: Theory into Practice, New York: Macmillan Publishing Company, 1986

Chatarina Tri Anni, Psikologi Belajar. Semarang: UPT MKK UNNES, 2005

Dahar, R. W, Teori-Teori Pembelajaran, Jakarta: Erlangga, 2011

Depdiknas, Permendiknas Nomor 22 Tahun 2006 Tentang Standar Isi Sekolah Menengah Atas. Jakarta: Depdiknas, 2006.

Drisscoll, M.P, Psichologi of Learning for Intruction, New Jersey: Pearson Education, 2005

Estiningsih, E, Landasan Teknik Pengajaran Hitung SD. Yogyakarta: PPPG Matematika, 1994

Gagne, Robert, The Conditioning of Learning, Japan: Holt Saunders, 1983

Hamzah, Upu, Teori Belajar Pendukung Pendekatan Pengajuan Masalah Matematika, 2008

Harefa, Andreas. Menjadi Manusia Pembelajar, Jakarta: Kompas, 2000

Hurlock, Elizabeth B, Perkembangan Anak Jilid 1.Jakarta: Erlangga, 2001

Lutan, Rusli, Belajar Keterampilan Motorik Pengantar Teori dan Metode, Jakarta: P2LPTK Dirjen Dikti Depdikbud, 1988

McDevitt, T. M., dan Ormrod, J. E, Child development: Educating and working with children and adolescents, 2nd ed, Upper Saddle River: Pearson Merrill Prentice Hall, 2002

Paulina, P. dan Malati, I, Strategi Kognitif, Jakarata: Direktorat Jendral Pendidikan Tinggi Departemen Pendidikan Nasional, 1997

Reid, B. Cognitive Strategy Instruction, Lincoln: Dept. of Special Ed \& Communication Disorders, 2006

Slameto, Belajar dan Faktor-Faktor yang Mempengaruhinya, Jakarta: Rineka Cipta, 2003 
126 Konsep Pembelajaran Matematika …..... Mariam Nasution

. Belajar dan Faktor-Faktor yang Mempengaruhinya, Jakarta: Rineka Cipta, 2010

Siregar, Evelin dan Hartini Nara., Teori Belajar dan Pembelajaran, Bogor: Ghalia Indonesia, 2011

Trianto. Model Pembelajaran Terpadu, Jakarta: Bumi Aksara, 2015 